\section{Demand and Characteristics of Customers of Reusable Products in Slovenia}

\author{
Katja Zajko \\ Recosi d.o.o., so.p., Slovenska Bistrica, Slovenia \\ katja.zajko@recositech.si \\ Barbara Bradač Hojnik \\ University of Maribor, Faculty of Economics and Business, Slovenia \\ barbara.bradac@um.si
}

\begin{abstract}
The main aim of the paper is to analyse whether a demand for reusable products in Slovenia exists and to identify customers' characteristics in terms of their gender, age, income, education and employment status. We used survey data to investigate what share of customers in Slovenia are buying and are willing to buy reusable products. Furthermore, we investigate whether there are differences between customers who are buying and who are not buying reusable products with regard to selected demographics (gender, age, income, education and employment status). The findings show that more than half of customers in Slovenia are already buying reusable products. The results of selected characteristics of individuals indicate that there are differences among buyers and non-buyers of reusable products only with regard to gender. The paper contributes to the literature on the demand for reusable products and gives better insights into the characteristics of customers buying reusable products.
\end{abstract}

Keywords: reusable products, demand, customer segmentation, Slovenia

\section{Introduction}

In the business environment, the concept of the circular economy is a relatively new and fast-developing topic, which is gathering researchers' attention because of its environmental impact. Consequently, new business models have emerged that have the potential to alter the ways in which we think about our role within economic systems. Prominent among these is the concept of reuse, which is an important part of the social movement that aims for ethical, responsible and sustainable consumption (Zajko \& Bradač Hojnik, 2018). A vital part of any system that aims to achieve reuse is to generate and sustain markets for products that have been refurbished. Currently, the reuse market is mainly focused on online platforms (such as eBay), flea markets and second-hand dealers. What is meant by the term 'reusable product' is that the product can be used several times for an intended end use (Premm, 2012) before being discarded.

In order to reach the set targets of Directive 2008/98/EC (the Waste Framework Directive) to have the highest possible rates of reuse, it is necessary to boost the demand and encourage as many companies as possible to get active in the business
ORIGINAL SCIENTIFIC PAPER

RECEIVED: JULY 2019

REVISED: AUGUST 2019

ACCEPTED: SEPTEMBER 2019

DOI: 10.2478/ngoe-2019-0014

UDK: 366.12:339.162.3:005.311

JEL: Q21, L31

Citation: Zajko, K., \& Bradač Hojnik, B. (2019). Demand and Characteristics of Customers of Reusable Products in Slovenia. Naše gospodarstvo/Our Economy, 65(3), 63-72. DOI: 10.2478/ ngoe-2019-0014

\section{NG OE}

NAŠE GOSPODARSTVO OUR ECONOMY

\section{vol.65 No.3 2019}

pp. $63-72$ 
field of reuse. The Waste Framework Directive sets the basic concepts and definitions related to waste management, including definitions of waste, recycling, reuse and recovery. It explains when waste ceases to be waste and becomes a secondary raw material (so called end-of-waste criteria), as well as how to distinguish between waste and by-products. Waste legislation and policy of the EU Member States shall apply the following waste management hierarchy (Premm, 2012): prevention, reuse, recycling, recovery and disposal.

While several prior studies (e.g., Flash Eurobarometer, 2011; Matos \& Silvestre, 2013; Matsumoto, 2010) have investigated the reuse concept, there is still a lack of research that would explore demand and customer segmentation for reusable products. Additionally, customers' preferences are changing over time. Therefore, the purpose of this paper is to study the demand for reusable products in Slovenia. Furthermore, the aim is to empirically test whether differences exist between buyers and non-buyers of reusable products with regard to selected demographic characteristics.

The first part of the paper reviews the literature to provide an overview of the consumption of reusable products as a crucial factor to ensure the economical continuity and sustainability of reuse businesses. This is followed by a discussion of customers' buying behaviours and preferences. The theoretical framework concludes with market demand and customers' willingness to buy reusable products, which is indispensable to sustain reuse businesses. The empirical part of the paper first employs a binomial test, which provides evidence of existing demand for reusable products and evidence for willingness to buy reusable products in Slovenia. Further, the empirical part employs a nonparametric test and t-test, which provide details about differences between buyers and non-buyers of reusable products with regard to selected demographic characteristics (i.e., gender, age, income, education and employment status). The paper concludes by revealing the results of the empirical analysis in comparison to some other research results.

\section{Literature Review}

Throughout the last two decades, the rapid growth of reusable product consumption has gained the attention of researchers and raised the question of why customers purchase reusable products. One answer to this question is that, due to economic and ecological reasons, some customers are now more interested in reusable products rather than new products (Guiot \& Roux, 2010). The longer product lifetime achieved through reuse gives an opportunity for recycling technologies to develop and for preserving a larger stock of resources for the future. The consumption of reusable products is also considered one of the best strategies to protect the environment, as it saves natural resources for making new products as well as protects the environment by preventing the used products from becoming waste (Yeh et al., 2010). Reuse is the only way to conserve the many critical raw materials for which no recycling technologies exist. For example, the manufacturing of electrical and electronic equipment (e.g., flat televisions, desktop computers, laptops and smartphones) is dependent on the supply of several metals that are classified as critical. There is currently no recovery of the high-tech elements antimony, arsenic, beryllium, silicon, gallium, germanium, and rare earth elements, while there are close to zero recovery rates for tantalum, lithium, and magnesium. The longer lifetime achieved through reuse thus gives an opportunity for such recycling technologies to develop and keeps a larger stock of resources for the urban mine of the future (Chancerel et al., 2015).

However, many customers may feel uncertain about the quality of the reusable products and instead would rather purchase new products, especially when a warranty is provided (Yeh et al., 2010). Therefore, a clear signal of quality is crucial in instilling confidence in customers. Additionally, public awareness, branding and warranty options have to be developed to generate the right conditions for a market for reused equipment to flourish (O’Connell \& Fitzpatrick, 2013). A public awareness campaign is also a crucial element, as final markets for the reusable products are essential for the on-going success of reusable products' companies. This campaign should focus on the job creation, value for money and environmental benefits that reuse brings and should be undertaken through the national and local media as well as on-line advertising and social networks. A reuse organisation should have its own unique brand and labelling scheme, with clearly visible labels on reusable product fit for resale. The unique brand and label will enable customers to identify the product they are purchasing as a reusable product that has been refurbished to a predefined standard, has a warranty of a definite duration and has aided in the provision of employment (O’Connell \& Fitzpatrick, 2013). The warranty is a fundamental aspect of electrical and electronic equipment reuse for promoting customer confidence.

Customers sometimes exhibit a negative attitude towards used products; however, change is evident in their shopping habits and preferences. Nonetheless, although in recent years it has become increasingly common for customers to choose products that correspond with their ethics, such as those based on environmental issues, customers' negative attitudes toward reusable products often remain a major obstacle for reuse businesses. There could also be differences in customer preferences due to cultural differences. According to Sundin et al. (2008), the potential reasons why remanufacturing has more potential for success in the U.S. 
compared to Sweden are cultural behaviour, customers' closeness to a reuse market, and higher focus on price. This illustrates that customers' preferences differ between countries, which leads to differences in reuse markets.

Customer behaviour is a key factor to consider in the reuse of products (e.g., Afroz et al., 2013; Dindarian et al., 2012; Gutiérrez et al., 2010). The progress of technology and short-term trends lead to more acquisitions, mainly of new products. Additionally, such progress cuts the usage time of products (Babbitt et al., 2009), which are replaced by either new products or reused ones and are rarely repaired (e.g., Hennies \& Stamminger, 2016; Sabbaghi et al., 2016; Scott \& Weaver, 2014). Another study among 115 customers from the UK (Cox et al., 2013) revealed that they expect constant and rapid updating of products. In particular, having the latest versions of products is strongly associated with personal identity and feelings of success in life. Such customers do not prefer to buy reused or second-hand products.

The empirical evidence on reusable product demand reveals heterogeneous results regarding buying or willingness to buy reusable products. Regarding reusable product acquisition, some studies revealed that customers are against buying reusable products. Fisher et al. (2005) found that people are concerned about potential premature failure and hygiene of reusable products. Lyndhurst (2011) claimed that people are frightened of reusable products and that they generally want to obtain new products (Watson, 2008). A survey conducted by Flash Eurobarometer (2011) estimated EU citizens' perceptions, attitudes and practices concerning resource efficiency, waste management and recycling. A sample size of 1,000 individuals aged 15 and older was used for each country within the EU-27. EU Citizens' willingness to buy second-hand products and reasons for not buying second-hand products were two categories within the survey. Customers' willingness to buy furniture, electronic equipment and textiles were compared, as were the reasons negative respondents gave for not buying second-hand products. Almost 7 out of 10 (68\%) EU citizens expressed willingness to buy second-hand furniture, electronic equipment or textiles. A majority (56\%) of EU citizens said they would buy second-hand furniture, while less than half (45\%) said they would buy electronic equipment, and a comparatively smaller proportion (36\%) said they were willing to buy second-hand textiles (e.g., clothing, bedding or curtains). Furthermore, results for Slovenian customers were above the average, as $72 \%$ were willing to buy second-hand products. Specifically, respondents indicated they would be willing to buy used furniture (57\%), electronic equipment (55\%) and textiles (30\%).

The latest study by Flash Eurobarometer (2014) about attitudes of Europeans towards waste management and resource efficiency revealed slightly different results in terms of willingness to buy particular types of reusable products. In this study, only $16 \%$ of EU citizens indicated that they would not buy any reusable products, while 84\% expressed willingness to buy second-hand products. For example, 55\% said they would buy second-hand furniture, $44 \%$ would buy second-hand electronic equipment, and 34\% would be second-hand textiles, while more than seven out of ten people (72\%) would purchase second-hand books, CDs, DVDs or video games. The same report revealed that the main factors that prevent people from buying second-hand goods are the perception of inferior quality and health and safety concerns. For Slovenia, the 2014 Flash Eurobarometer study found higher levels of willingness to buy reusable products than did the previous one in 2011. Almost 8 out of 10 respondents (79\%) expressed willingness to buy any of the listed second-hand products. Specifically, respondents indicated their willingness to buy second-hand books, CDs, DVDs and video games (62\%), furniture (47\%), electronic equipment (43\%), household electrical appliances (38\%) and textiles (30\%). However, the results for Slovene customers who expressed willingness to buy second-hand products were below the EU average.

Nevertheless, the willingness to buy is only an indicator, which does not show the real but only the potential purchase of reusable products. Studies measuring actual reusable product purchases revealed much lower shares of reusable product buyers. For example, a study conducted in Spain (Bovea et al., 2017) showed that less than 1\% of participants has ever bought second-hand small household electrical and electronic equipment. The main reasons given for the low rate were the cost of second-hand products (similar to that of new equipment) and hygiene and cleaning concerns.

Although prior studies have been conducted regarding the willingness to buy and actual purchase of reusable products, results are divergent and consequently require additional insight into the topic. Therefore, we formulated two hypotheses, one dealing with the actual purchase and the other with willingness to purchase reusable products. Regarding the first hypothesis, where we will examine the actual buying of reusable products, we used the threshold of 50\%, because previous studies (e.g., Bovea et al., 2017; Flash Eurobarometer, 2014) showed diversified results. However, this share is expected to be lower than the willingness to buy reusable products.

Regarding measuring the willingness to buy reusable products in the second hypothesis, we will test whether more than $70 \%$ of individuals are willing to buy reusable products. This proportion has been used because some previous studies (e.g., Flash Eurobarometer, 2011, 2014) showed similar shares, but there is a lack of evidence concerning the 
time stability of the proportion. Therefore, this study aims to address this issue by investigating whether the proportion is changing over time. Regarding the above-discussed issues, the following two hypotheses are presented:

H1: More than $50 \%$ of individuals in Slovenia are actually buying reusable products.

H2: More than $70 \%$ of those who do not currently buy reusable products in Slovenia are willing to buy them.

Previous studies have revealed that consumers' buying behaviour is generally influenced by two important sets of factors (Solomon et al., 2013): individual factors (e.g., demographics, customer's perception, knowledge, inspiration, learning, personality, attitude, thoughts and lifestyle) and environmental factors (e.g., culture, the reference group, social class, family and household). For example, gender is an important variable used in marketing to segment customers (Meyers-Levy \& Strenthal, 1991). The influence of gender upon decision-making and shopping behaviour has been a subject of special interest in the field of marketing (Hernandez et al., 2011). Generally speaking, shopping is stereotypically considered a female activity (Buttle, 2006). Research by Global Marketing Insight revealed that the channels and reasons for choosing reused items differ by age group and gender. Charity shops are the most popular offline destination for second-hand shopping. Almost seven out of $10(67 \%)$ respondents in one study have bought items in a charity shop, and they are more popular with women than men. Furthermore, a third of customers are buying more second-hand items than they were 12 months ago, and more women than men are happy to rummage through vintage or used items (Chahal, 2013).

Additionally, there are some other factors (e.g., price, brand, risk and location) that customers consider while buying a product (Sata, 2013). Influential factors also differ based on the product category, customer personality and demographic characteristics (e.g., Fortuna \& Diyamandoglu, 2017). For example, when customers choose an automobile brand, they consider quality and price as the most important factors. For sensitive electronic products like mobile phones, price and features become important factors for customers.

Some other circumstances also contribute to demand for reusable products. One of these is that some consumers may be in a relatively more challenging economic situation that impacts the demand for reusable products (Austin et al., 2006). Many people simply cannot afford classy and expensive products (e.g., clothes or furniture). This group of potential customers might encompass students, seasonal workers, immigrants, refugees and other disadvantaged people. According to Williams and Paddock (2003), disadvantaged people who are unable to buy new goods from formal retail outlets are the primary users of second-hand stores. As reported by Williams and Paddock (2003), even economically rational customers (those who like to take the best action for utility maximization to get the best payoffs) (Shugan, 2006) are involved in the reuse market. According to Guiot and Roux (2010), due to the economic crisis and the consequent drop in purchasing power, the middle class has become more involved within the reuse market and has begun purchasing more reusable products. However, an assumption that only the lower and middle classes are involved in the second-hand market would be incorrect. A study of Scitovsky (1994) showed that the upper class is also involved in the reuse market and how the reuse market is used by different economic classes of people.

Considering previous studies and their results from examining customers' behaviour from different perspectives, our third hypothesis refers to differences in demographic characteristics between individuals who are buying reusable products and those who are not. These are important aspects for reuse organisations to consider in order to address their selling efforts to the right groups of people to achieve the best results. Therefore, we will test differences between these two groups for several characteristics - gender, age, income, education and employment status — using our third hypothesis, with sub-hypotheses for each demographic characteristic:

H3: Differences exist in demographic characteristics between groups of individuals who do and do not buy reusable products. Specifically, such differences exist in terms of a) gender, b) age, c) income, d) education, and e) employment status.

\section{Research Methodology and Data}

The paper is based on empirical research using a survey, which included a convenience sample of 599 individuals in Slovenia, aged 15 years or older. This study was conducted generally for all types of reusable products. Data were collected from September till November 2015, using a structured questionnaire that consisted of 6 demographic questions and 13 closed-ended questions. Data were collected in two ways: using an online survey tool and from random visitors in front of the two biggest shopping centres in Slovenia, one in Maribor and one in Ljubljana. Email addresses were acquired from the conference of Integral Green Economy for Better World, and questionnaires were sent out to more than 400 recipients, 99 of whom responded. The face-to-face survey was carried out with 500 random visitors in front of shopping centres. The set of demographic 
questions included questions about gender, age group, income level, educational level, employment status and region. We included dichotomous questions, questions with multiple answers, and questions for which respondents evaluated the importance of the argument based on a fivepoint Likert scale. Before the survey was conducted, the questionnaire was pilot tested on 10 people. Based on the results and comments from tested respondents, we adjusted the questions accordingly.

The collected data were processed using the program SPSS Statistics 21.0. For testing the hypotheses, we used a binomial test, Mann-Whitney test and t-test.

In the analysis, the following variables were used:

- Willingness to buy reusable products: Respondents were asked whether they were prepared to buy a reusable product in the future. Only individuals who answered that they had never bought a reusable product were asked this question.

- Actual buying of reusable products: Respondents were asked whether or not they currently buy reusable products.

- $\quad$ Respondents' gender: 1 = male, 2 = female.

- Respondents' age: Age was grouped into 4 categories: $1=15$ to 30 years, $2=31$ to 40 years, $3=41$ to 50 years, and $4=51$ years or older.

- Respondents' income: Income was grouped into 6 categories: $1=400$ EUR or less, $2=401$ to 600 EUR, $3=$ 601 to 1000 EUR, $4=1001$ to 1500 EUR, 5 = 1501 to 2000 EUR, and 6 = 2001 EUR or more.

- Respondents’ education: Education was grouped into 4 groups according to their completed educational level: 1 = primary school, 2 = secondary education, 3 = post-secondary or bachelor's education, 4 = master's education or higher.

- Respondents’ employment status: employment status was measured by 6 groups: 1 = unemployed, 2 = employed, 3 = company owner, 4 = farmer, 5 = retired, and $6=$ student.

\section{Data Analysis and Results}

To test the first hypothesis, regarding whether more 50\% of individuals in Slovenia are buying reusable products, we used the binomial test. The actual buying of reusable products was tested among 599 respondents who answered whether or not they were currently buying reusable products or not. In this case we also set a null hypothesis (H0) and alternative hypothesis (H1):

H0: $\pi \leq 0.5$ (The proportion of those who are buying reusable products is less than or equal to $50 \%$ ).
$\mathrm{H} 1: \pi>0.5$ (The proportion of those who are buying reusable products is higher than $50 \%$ ).

The results of the binomial test (Table 1) indicate that the observed proportion of actual buyers of reusable products is 0.56 and is statistically significantly higher than the expected $0.5, \mathrm{p}=0.005$ (2-sided).

Table 1. Binomial test results for actual buying of reusable products in Slovenia

\begin{tabular}{ccccc}
\multicolumn{5}{c}{ Actual buying of reusable products in Slovenia } \\
\hline Category & $\mathrm{N}$ & $\begin{array}{c}\text { Observed } \\
\text { Proportion }\end{array}$ & $\begin{array}{c}\text { Test } \\
\text { Proportion }\end{array}$ & $\begin{array}{c}\text { Exact Sig. } \\
\text { (2-tailed) }\end{array}$ \\
\hline Yes & 334 & 0.56 & 0.50 & 0.005 \\
\hline No & 265 & 0.44 & & \\
\hline Total & 599 & 1.00 & & \\
\hline
\end{tabular}

With a significance level of 0.005 , we can conclude that more than $50 \%$ of customers do buy reusable products in Slovenia, supporting H1. Confirming this hypothesis means that in the Slovene market more than $50 \%$ of customers are already buying reusable products, and therefore a demand exists for these products. Our results indicate that the proportion of individuals in Slovenia who are already buying reusable products is higher compared to the findings of some other studies (e.g., Bovea et al., 2017; Flash Eurobarometer, 2011, 2014).

To test the second hypothesis, regarding whether more than $70 \%$ of individuals in Slovenia are willing to buy reusable products, we also used a binomial test. The willingness to buy reusable products was tested among respondents who answered that they had never bought a reusable product $(n=286)$. Respondents answered this question with "yes" or "no". In order to carry out the binomial test, we set a null hypothesis (H0) and alternative hypothesis (H1):

H0: $\pi \leq 0.7$ (The proportion of those who are willing to buy reusable products is less or equal to $70 \%$ ).

H1: $\pi>0.7$ (The proportion of those who are willing to buy reusable products is higher than $70 \%$ ).

The results of the binomial test (Table 2) indicate that the observed proportion of individuals who are willing to buy reusable products in the future is 0.7 , which is equal to the test proportion $0.7, \mathrm{p}=0.512$ (1-sided). Therefore, we cannot reject the null hypothesis and thus cannot confirm our second hypothesis that more than $70 \%$ of individuals in Slovenia are willing to buy reusable products in the future. Compared to previous studies (e.g., Flash Eurobarometer, 2011, 2014), our results indicate lower levels of willingness 
to buy reusable products. This could be the result of the better economic situation of respondents, because unlike the earlier surveys, our survey was conducted well after the recent economic crisis.

Table 2. Binomial test results for willingness to buy reusable products in the future

\begin{tabular}{lccccc}
$\begin{array}{l}\text { Willingness to buy } \\
\text { reusable products } \\
\text { in the future }\end{array}$ & $\mathbf{N}$ & $\begin{array}{c}\text { Observed } \\
\text { Proportion }\end{array}$ & $\begin{array}{c}\text { Test } \\
\text { Proportion }\end{array}$ & $\begin{array}{c}\text { Exact Sig. } \\
\text { (1-tailed) }\end{array}$ \\
\hline & Yes & 200 & 0.70 & 0.70 & $0.512^{\mathrm{a}}$ \\
\cline { 2 - 6 } Valid & No & 86 & 0.30 & & \\
\cline { 2 - 6 } & Total & 286 & 1.00 & 0 & \\
\hline
\end{tabular}

a Alternative hypothesis states that the proportion of cases in the first group $<0.70$.

To test the third hypothesis, regarding whether differences exist in demographic characteristics between individuals who buy reusable products and individuals who do not buy reusable products, we used a Mann-Whitney non-parametric test and t-test. Differences in demographic characteristics were tested among respondents who answered that they buy reusable products (Group of buyers) and those who answered that they do not buy reusable products (Group of non-buyers). In Table 3, the descriptive statistics results of demographic characteristics for both groups (buyers and non-buyers) are presented.

Descriptive statistics results in Table 3 show the results of each of the five analysed demographic characteristics. We can see that in the Group of buyers is found a higher proportion of men (39.52\%) than in the Group of non-buyers (26.42\%). The proportion of men in the Group of buyers is also slightly higher than the proportion of men in the selected sample, where it is $33.72 \%$. Further, results show that the Group of non-buyers has a higher proportion of women (73.58\%) than the Group of buyers (60.56\%). Considering the age of respondents, the share of the Group of buyers of reusable products (44.61\%) is very similar to the share of non-buyers from 15 to 30 years of age (44.53\%). It is also interesting that in the Group of non-buyers a higher proportion of people over 51 years of age (22.26\%) is present than in the Group of buyers (17.66\%). Regarding the income categories, the highest share of respondents belongs to the income category between 601 and 1000 euros in both groups. In the Group of buyers, we identified a higher proportion of respondents in the lowest income category — up

Table 3. Descriptive statistics results of demographic characteristics for Group of buyers and Group of non-buyers

\begin{tabular}{|c|c|c|c|c|c|c|c|}
\hline & & \multicolumn{2}{|c|}{ Group of buyers } & \multicolumn{2}{|c|}{ Group of non-buyers } & \multicolumn{2}{|c|}{ Total } \\
\hline & & Frequency & Percent & Frequency & Percent & Frequency & Percent \\
\hline & 1. Men & 132 & 39.52 & 70 & 26.42 & 202 & 33.72 \\
\hline \multirow[t]{4}{*}{ Gender } & 2. Women & 202 & 60.48 & 195 & 73.58 & 397 & 66.28 \\
\hline & Total & 334 & 100.00 & 265 & 100.00 & 599 & 100.00 \\
\hline & $1.15-30$ years of age & 149 & 44.61 & 118 & 44.53 & 267 & 44.57 \\
\hline & 2. $31-40$ years of age & 86 & 25.75 & 55 & 20.75 & 141 & 23.54 \\
\hline \multirow[t]{6}{*}{ Age } & 3. $41-50$ years of age & 40 & 11.98 & 33 & 12.45 & 73 & 12.19 \\
\hline & 4. Above 51 years of age & 59 & 17.66 & 59 & 22.26 & 118 & 19.70 \\
\hline & Total & 334 & 100.00 & 265 & 100.00 & 599 & 100.00 \\
\hline & 1. 400 EUR or less & 47 & 14.11 & 33 & 12.60 & 80 & 13.45 \\
\hline & 2. From 401 to 600 EUR & 92 & 27.63 & 70 & 26.72 & 162 & 27.23 \\
\hline & 3. From 601 to 1000 EUR & 121 & 36.34 & 107 & 40.84 & 228 & 38.32 \\
\hline \multirow[t]{6}{*}{ Income } & 4. From 1001 to 1500 EUR & 52 & 15.62 & 42 & 16.03 & 94 & 15.80 \\
\hline & 5. From 1501 to 2000 EUR & 14 & 4.20 & 9 & 3.44 & 23 & 3.87 \\
\hline & 6. 2001 EUR or more & 7 & 2.10 & 1 & 0.38 & 8 & 1.34 \\
\hline & Total & 333 & 100 & 262 & 100 & 595 & 100 \\
\hline & 1. Primary school & 10 & 2.99 & 8 & 3.04 & 18 & 3.02 \\
\hline & 2. Secondary School & 168 & 50.30 & 127 & 48.29 & 295 & 49.41 \\
\hline \multirow[t]{3}{*}{ Education } & 3. Post-Secondary or Bachelor & 128 & 38.32 & 114 & 43.35 & 242 & 40.54 \\
\hline & 4. Master or more & 28 & 8.38 & 14 & 5.32 & 42 & 7.04 \\
\hline & Total & 334 & 100.00 & 263 & 100.00 & 597 & 100.00 \\
\hline
\end{tabular}


to 400 euros $(14.11 \%)$ - than in the Group of non-buyers (12.60\%). Results show that there are more non-buyers in the category between 601 and 1000 euros (40.84\%) than in the Group of buyers (36.34\%). Regarding educational structure, in both groups (buyers and non-buyers of reusable products) the largest proportion of respondents has a secondary education. There are more non-buyers with completed primary education (3.04\%) than buyers (2.99\%). Additionally, there are more buyers with post-secondary education or a bachelor's degree (43.35\%) than non-buyers (38.32\%). Regarding employment status, the descriptive statistics results indicate that in both groups (buyers and non-buyers of reusable products), the highest proportion of respondents belong to the employed group. However, we can see that among students and retired persons, there are more non-buyers than buyers of reusable products.

Finally, we tested whether statistically significant differences exist between the two groups (buyers and non-buyers of reusable products) based on the demographic characteristics described above. To test the first sub-hypothesis H3a, regarding whether differences exist in gender between buyers and non-buyers of reusable products, we used the Mann-Whitney test (the Kolmogorov-Smirnov test indicates that the variable is not normally distributed, $\mathrm{D}(599)=0.131, \mathrm{p}=0.012)$. The t-test was used for testing the four other demographic characteristics. Table 4 shows the results regarding gender between the Group of buyers and Group of non-buyers, and Table 5 shows the results of the Mann-Whitney test.

Table 4. Results regarding differences in gender between Group of buyers and Group of non-buyers of reusable products

\begin{tabular}{lcccc} 
Characteristic & Group & N & Mean Rank & $\begin{array}{c}\text { Sum } \\
\text { of Ranks }\end{array}$ \\
\hline \multirow{3}{*}{ Gender } & Buyers & 334 & 282.63 & 94400.00 \\
\cline { 2 - 5 } & Non-buyers & 265 & 321.89 & 85300.00 \\
\cline { 2 - 5 } & Total & 599 & & \\
\hline
\end{tabular}

Table 5. Results of Mann-Whitney test regarding differences in gender between Group of buyers and Group of non-buyers of reusable products

\begin{tabular}{lc} 
& Gender \\
\hline Mann-Whitney U & 38455.000 \\
\hline Wilcoxon W & 94400.000 \\
\hline$Z$ & -3.367 \\
\hline Asymp. Sig. (2-tailed) & 0.001 \\
\hline Exact Sig. (2-tailed) & 0.001 \\
\hline Exact Sig. (1-tailed) & 0.000 \\
\hline Point Probability & 0.000 \\
\hline
\end{tabular}

A Mann-Whitney test indicates that there are differences in gender between the Group of individuals who buy reusable products and Group of individuals who do not buy reusable products $(\mathrm{U}=38455$, $\mathrm{p}=0.001)$. Therefore, the sub-hypothesis HЗa is confirmed.

Based on the results of the t-test for the other demographic characteristics, we could not confirm differences in buying reusable products regarding respondents' age $(\mathrm{t}(549.038)=-$ 1.012, $\mathrm{p}=0.312$ (2-sided)), income $(\mathrm{t}(593)=0.261, \mathrm{p}=0.794$ (2-sided)), educational level $(t(595)=0.207, p=0.836$ sided)) or employment status $(\mathrm{t}(597)=-1.044, \mathrm{p}=0.297$ (2sided)), in contrast to some previous research (e.g., Fortuna and Diyamandoglu, 2017). Consequently, we could not confirm sub-hypotheses H3b-H3e regarding differences in age, income, education and employment status between Group of individuals who buy reusable products and Group of individuals who do not buy reusable products. Therefore, the results only partially support our third hypothesis, because we could confirm that differences exist in demographic characteristics based on gender between individuals who buy reusable products and individuals who do not buy reusable products. Our results indicate that the share of people buying reusable products is equally distributed in the age, education, income and employment status categories.

\section{Conclusions and Discussion}

The findings of this study provide evidence of the demand for reusable products in Slovenia regarding the selected demographic characteristics of buyers and non-buyers of reusable products. In particular, the findings support the existence of demand and existence of particular groups of customers of reusable products based on demographic characteristics.

Using a binomial test, we tested our first hypothesis that more than $50 \%$ of customers in Slovenia are buying reusable products. The results showed that $56 \%$ of customers in our sample are indeed buying reusable products in Slovenia. Therefore, we confirmed our first hypothesis. Additionally, this means that in Slovenia there exists a demand for reusable products. Our results are consistent with prior findings (Matsumoto, 2010), suggesting that for sustaining reuse business, sufficient market demand is essential.

Our results could not confirm that more than $70 \%$ of the participants in our sample are willing to buy reusable products, which could be the result of the improved economic situation in Slovenia since the recent economic crisis, as our survey was conducted later than previous ones (e.g., Flash Eurobarometer, 2011, 2014). Therefore, we could not confirm our second hypothesis. The results obtained in this 
study contribute to the knowledge about the perceptions of reusable products and particularly the willingness to buy reusable products. However, despite the existence of the demand for reusable products in Slovenia, there is still a need for more promotion among enterprises operating as reuse organisations and a need to offer high-quality and safe products, as the success of reuse activities strongly depends on the trust of customers in the quality and safety of the reusable products.

The analysis of differences among selected demographic characteristics (gender, age, income, education and employment status) revealed that there are statistically significant differences between men and women with regard to buying reusable products. Namely, a significantly higher share of women than men are buying reusable products in Slovenia. Also other studies (e.g., Chahal, 2013) from different markets report differences in buyers' demographic characteristics.

Furthermore, the present study revealed that in the sample, results show significant differences between buyers and non-buyers of reusable products with regard to gender. However, significant differences could not be confirmed for the other demographic characteristics (age, income, education and employment status). This suggests that older or younger people that people who have often less income, or people with lower educational levels (who also have often lower income) do not buy reusable products more often than those of different ages, with higher incomes, or with higher educational levels. Therefore, the third hypothesis, that differences exist between buyers and non-buyers of reusable products based on demographic characteristics, can be only partially confirmed.

The results provide important information in several ways. Firstly, it is very important to understand the market and demand for reuse organisations to provide a continuous economic activity. Therefore, this paper contributes to the literature on the demand for reusable products and gives better insights into the demographic characteristics of customers of reusable products. This offers important directions for other researchers in the area of reuse industry. Secondly, this analysis provides detailed insight into characteristics of potential customers for reusable products. It is relevant for potential entrepreneurs in the reuse industry to use this analysis as an indicative tool for their market research on customers' behaviour. They can better understand and compare target groups of potential customers of reusable products and thereby the results may help them in decision-making about the reuse company establishment. The article has several limitations, among which are focusing on all reusable products and on sample in only one country. However, further research using different types of reusable products or reasons for buying reusable products could provide additional evidence, offering better insights into customers' behaviour patterns when buying reusable products. Moreover, an empirical analysis using a cluster analysis could be useful for reuse organisations to better understand customers' segmentation.

\section{References}

Afroz, R., Masud, M. M., Akhtar, R., \& Duasa, J. B. (2013). Survey and analysis of public knowledge, awareness and willingness to pay in Kuala Lumpur, Malaysia - a case study on household WEEE management. Journal of Cleaner Production, 52(1), 185-193. https://doi. org/10.1016/j.jclepro.2013.02.004

Austin, M.P., Belbin, L., Meyers,J.A., Doherty, M.D., \& Luoto, M.(2006). Evaluation of statistical models used for predicting plant species distributions: Role of artificial data and theory. Ecological Modelling, 199(2), 197-216. https://doi.org/10.1016/j.ecolmodel.2006.05.023

Babbitt, C., Ramzy, K., Williams, E., \& Babbitt, G. (2009). Evolution of product lifespan and implications for environmental assessment and management: A case study of personal computers in higher education. Environmental Science \& Technology, 43(13), 5106-5112. https://doi.org/10.1021/es803568p

Bovea, D. M., Pérez-Belis, V., \& Quemades-Beltrán, P. (2017). Attitude of the stakeholders involved in the repair and second-hand sale of small household electrical and electronic equipment: Case study in Spain. Journal of Environmental Management, 1(196), 91-99. https://doi.org/10.1016/j.jenvman.2017.02.069

Buttle, F. (2006). Shopping motives constructionist perspective. The Service Industries Journal, 12(3), 349-367. https://doi. org/10.1080/02642069200000044

Chahal, M. (2013). The second-hand market: What consumers really want to buy. Retrieved from: https://www.marketingweek. com/2013/10/21/the-second-hand-market-what-consumers-really-want-to-buy/

Chancerel, P., Marwede, M., Nissen, N. F., \& Lang, K. D. (2015). Estimating the quantities of critical metals embedded in ICT and consumer equipment. Resources, Conservation and Recycling, 98, 9-18. https://doi.org/10.1016/j.resconrec.2015.03.003

Cox, J., Griffith, S., Giorgi, S., \& King, G. (2013). Consumer understanding of product lifetimes. Resources, Conservation and Recycling, 79 , 21-29. https://doi.org/10.1016/j.resconrec.2013.05.003

Dindarian, A., Gibson, A. A. P., \& Quariguasi-Frota-Neto, J. (2012). Electronic product returns and potential reuse opportunities: A microwave case study in the United Kingdom.Journal of Cleaner Production, 32, 22 -31. https://doi.org/10.1016/j.jclepro.2012.03.015 
Fisher, M. M., Mark, F. E., Kingsbury, T., Vehlow, J., \& Yamawaki, T. (2005). Energy recovery in the sustainable recycling of plastic from end-of-life electrical and electronic products. In: International Symposium on Electronics and the Environment (2005 ISEE/Summit).

Flash Eurobarometer. (2011). Attitudes of Europeans towards resource efficiency. Analytical report, Flash EB Series No. 316. Brussels: European Commission.

Flash Eurobarometer. (2014). Attitudes of Europeans towards waste management and resource efficiency. Report, Flash EB Series No. 388. Brussels: European Commission.

Fortuna M. L., \& Diyamandoglu, V. (2017). Disposal and acquisition trends in second-hand products. Journal of Cleaner Production, 142(4), 2454-2462. https://doi.org/10.1016/j.jclepro.2016.11.030

Guiot, D., \& Roux, D. (2010). Second-hand shoppers' motivation scale: Antecedents, consequences, and implications for retailers. Journal of Retailing, 86(4), 383-399. https://doi.org/10.1016/j.jretai.2010.08.002

Gutiérrez, S. M., Camarero Izquierdo, C., \& San José Cabezudo, R. (2010). Product and channel-related risk and involvement in online contexts. Electronic Commerce Research and Applications, 9(3), 263-273. https://doi.org/10.1016/j.elerap.2009.09.005

Hennies, L., \& Stamminger, R. (2016). An empirical survey on the obsolescence of appliances in German households. Resources, Conservation and Recycling, 112, 73-82. https://doi.org/10.1016/j.resconrec.2016.04.013

Hernandez, B., Jimenez, J., \& Martin, M.J. (2011). Age, gender and income: Do they really moderate online behaviour? Online Information Review, 35(2), 144-126. https://doi.org/10.1108/14684521111113614

Lyndhurst, B. (2011). Public understanding of product lifetimes and durability. London, England: Defra.

Matos, S., \& Silvestre, B. S. (2013). Managing stakeholder relations when developing sustainable business models: The case of the Brazilian energy sector. Journal of Cleaner Production, 45, 61-73. https://doi.org/10.1016/j.jclepro.2012.04.023

Matsumoto, M. (2010). Development of a simulation model for reuse businesses and case studies in Japan. Journal of Cleaner Production, 18(13), 1284-1299. https://doi.org/10.1016/j.jclepro.2010.04.008

Meyers-Levy,J., \& Sternthal, B. (1991). Gender differences in the use of message cues and judgments.Journal of Marketing Research, 28(1), 84-96. https://doi.org/10.2307/3172728

O'Connell, M., \& Fitzpatrick, C. (2013). Re-evaluate reuse of electrical and electronic equipment (evaluation and mainstreaming), EPA STRIVE Report 2007-2013. Ireland: Environmental Protection Agency

Premm, M. (2012). Report on implementation models for repair and re-use networks. (WP 4.1.). CERREC - Central Europe Repair and Reuse Centres and Networks. Needs assessment and model development. Retrieved from: http://www.central2013.eu/fileadmin/user_upload/ Downloads/outputlib/CERREC_report_on_implementation_models.pdf

Sabbaghi, M., Behdad, S., \& Zhuang,J. (2016). Managing consumer behaviour toward on-time return of the waste electrical and electronic equipment: A game theoretic approach. International Journal of Production Economics, 182, 545-563. https://doi.org/10.1016/j. ijpe.2016.10.009

Sata, M. (2013). Factors affecting consumer buying behavior of mobile phone devices. Mediterranean Journal of Social Sciences, 4(12), 103-112. https://doi.org/10.5901/mjss.2013.v4n12p103

Scitovsky, T. (1994). Towards a theory of second-hand markets. Kyklos, 47, 33-52. https://doi.org/10.1111/j.1467-6435.1994.tb02247.x

Scott, K. A., \& Weaver, S. T. (2014). To repair or not to repair: What is the motivation? Journal for Research for Consumers, 26, 1-31.

Shugan, S. M. (2006). Are consumers rational? Experimental evidence? Marketing Science, 25(1), 1-7. https://doi.org/10.1287/ mksc.1060.0196

Solomon, M. R., Bamossy, G., Askegaard, S., \& Hogg, M. K. (2013). Consumer behavior: A European perspective (5th ed.). Harlow, England: Pearson Education Limited.

Sundin, E., Ostlin, J., \& Bjorkman, M. (2008). Why is remanufacturing more successful in the United States than in Sweden? Proceedings of 15 th CIRP International Conference on Life Cycle Engineering, Sydney.

Watson, M. (2008). A review of literature and research on public attitudes, perceptions and behaviour relating to remanufactured, repaired and reusable products. Report for the Centre for Remanufacturing and Reuse. Sheffield: The University of Sheffield.

Williams, C. C., \& Paddock, C. (2003). The meanings of informal and second-hand retail channels: Some evidence from Leicester. International Review of Retail, Distribution and Consumer Research, 13(3), 317-336. https://doi.org/10.1080/0959396032000101372

Yeh, R. H., Lo, H. C., \& Yu, R. Y. (2010). A study of maintenance policies for second-hand products. Computers \& Industrial Engineering, 60(3), 438-444. https://doi.org/10.1016/j.cie.2010.07.033

Zajko, K., \& Bradac, B. (2018). Social franchising model as a scaling strategy for ICT reuse: A case study of an international franchise. Sustainability, 10(9), 1-28. https://doi.org/10.3390/su10093144 


\section{Povpraševanje in značilnosti kupcev izdelkov ponovne uporabe $v$ Sloveniji}

\section{Izvleček}

Glavni cilj prispevka je analizirati, ali v Sloveniji obstaja povpraševanje po izdelkih ponovne uporabe in kakšne so značilnosti kupcev glede na spol, starost, dohodek, izobrazbo in status zaposlitve. Uporabljeno je bilo anketiranje za proučevanje deleža kupcev v Sloveniji, ki kupujejo, in tistih, ki so pripravljeni kupiti izdelke ponovne uporabe. Poleg tega preučujemo, ali obstajajo razlike med izbranimi demografskimi podatki (spol, starost, prihodek, izobrazba in zaposlitveni status) med tistimi, ki kupujejo, in tistimi, ki ne kupujejo izdelkov ponovne uporabe. Ugotovitve kažejo, da več kot polovica kupcev v Sloveniji že kupuje izdelke ponovne uporabe. Med izbranimi demografskimi značilnostmi vzorca smo uspeli dokazati statistično značilne razlike le med spoloma. Članek prispeva k literaturi o povpraševanju po izdelkih ponovne uporabe in daje vpogled v lastnosti kupcev izdelkov ponovne uporabe.

Ključne besede: izdelki ponovne uporabe, povpraševanje, segmentacija kupcev, Slovenija 